\title{
Analisis Tingkat Kesehatan Bank Menggunakan Metode RGEC Terhadap Harga Saham Bank Pembangunan Daerah Tahun 2014-2018
}

\author{
Shinta Gusti Maharani ${ }^{\bowtie}$, Aldilla Iradianty ${ }^{2}$ \\ 1,2 Manajemen Bisnis Telekomunikasi dan Informatika, Fakultas Ekonomi dan Bisnis, Universitas Telkom
}

\begin{abstract}
ABSTRAK
Hasil penelitian menunjukkan bahwa variabel tingkat kesehatan bank yaitu NPL, LDR, GCG, ROA, NIM, dan, CAR secara bersama-sama (simultan) berpengaruh signifikan terhadap harga saham. Sedangkan hasil dari pengujian secara parsial menunjukkan variabel NPL berpengaruh signifikan terhadap harga saham. Variabel LDR, GCG, ROA, NIM, dan CAR menunjukkan hasil bahwa variabel-variabel tersebut secara parsial tidak perpengaruh signifikan terhadap harga saham. Berdasarkan keterlibatan peneliti terhadap data, penelitian ini bersifat tidak mengintervensi data. Saran kepada para investor hendaknya mempertimbangkan analisis tingkat kesehatan bank serta memperhatikan faktor-faktor lain ketika akan mengambil keputusan investasi pada Bank Pembangunan Daerah. Kepada pihak bank yang bersangkutan pada penelitian ini diharapkan untuk lebih memperhatikan rasio keuangan Non Performing Loan (NPL)
\end{abstract}

\section{Kata-kunci:}

Kinerja karyawan, Tanggung jawab, Pemberian insentif

\begin{abstract}
This type of research is a quantitative approach. The sample in this study were 105 respondents who were taken with the saturated method. Data reliability analysis techniques, classical assumption test, determination coefficient test, and hypothesis testing. The calculation process is assisted by the SPSS 26 software application program. The test results show that incentives have a positive and significant effect on employee performance, responsibility has a positive and significant effect on employee performance, and incentives and responsibilities have a positive and significant effect on employee performance.
\end{abstract}

Keywords : Employee performance; Responsible; Incentives Giving

$\triangle$ Corresponding author :

Email Address : shinta23@yahoo.co.id

"Received 12, Agustus 2020, Accepted 15, Januari 2021, Published 06, Februari 2021" 


\section{Pendahuluan}

Keberadaan Bank Pembangunan Daerah begitu penting dalam perkonomian daerah. Bank Pembangunan Daerah memiliki fungsi untuk membantu pemerintah dalam hal kepentingan daerah berupa jasa pelayanan keuangan dan perbankan. Fungsi dari BPD yaitu untuk pengembangan perekonomian dari suatu daerah yang bertujuan untuk meningkatkan taraf hidup masyarakat daerah, menjadi sumber pembiayaan pembangunan daerah, menyimpan dana, dan mengelola keuangan daerah. Melihat pentingnya keberadaan BPD, maka sudah seharusnya BPD mampu untuk menjaga kesehatan banknya. Tingkat kesehatan bank ini dapat dilakukan dengan pendekatan Risk-Based Bank Rating (metode RGEC) dengan melakukan analisis komponen kesehatan bank, yaitu Risk Profile (Profil Risiko), Good Corporate Governance (GCG), Earning (Rentabilitas), dan Capital (Permodalan).

Otoritas Jasa Keuangan (OJK) mencatat per Desember 2018, diketahui total laba sebelum pajak Bank Pembangunan Daerah (BPD) sepanjang tahun 2018 mencapai Rp 15,157 miliar. Realisasi angka tersebut secara year on year (yoy) naik 3,9\% dibandingkan dengan tahun 2017 yang hanya sebesar Rp 14,584 miliar. Sedangkan, pendapatan laba bersih setelah pajak (Net Income After Tax) setelah dikurangi taksiran pajak pada 2018 mencapai Rp 13,090 miliar, tumbuh 5,4\% dibandingkan dengan realisasi pada 2017 sebesar Rp 12,421. Dalam 4 tahun kebelakang laba dari BPD terus mengalami kenaikan setiap tahunnya, dimana sebelumnya pernah mengalami penurunan laba di tahun 2014 sebesar 9,9\%. Merujuk pada data Bursa Efek Indonesia (BEI) per Desember 2018, diketahui ratarata harga saham BPD yang terdaftar di BEI mengalami pergerakan naik dan turun dari tahun 2014 sampai tahun 2018. Perubahan harga saham tersebut dapat disebabkan oleh faktor internal maupun faktor eksternal bank. Faktor internal seperti kinerja keunangan bank serta manajemen kinerja dalam penerapan prinsip-prinsip Good Corporate Governance. Kemudian faktor eksternal seperti inflasi, nilai kurs mata uang, dan faktor lain yang berhubungan dengan perdagangan saham di bursa efek. 
Pertumbuhan laba pada Bank Pembangunan Daerah dipengaruhi oleh rasio-rasio keuangan bank. Sehingga yang melatarbelakangi peneliti memilih obyek Bank Pembangunan Daerah (BPD) yaitu untuk mengatahui bagaimana pengaruh rasio keuangan serta manajemen kinerja berpengaruh terhadap harga saham melalui pendekatan RBBR (metode RGEC). Karena BPD menjadi salah satu bank yang memiliki potensi yang baik bagi perekonomian Indonesia khususnya di daerah-daerah. Tingkat kesehatan bank dapat menunjukkan kinerja dari BPD apakah baik atau buruk. Hasil dari penilaian tingkat kesehatan tersebut dapat memberikan dampak keputusan investor serta mempengaruhi kerpercayaan masyarakat kepada BPD. Apabila BPD memiliki tingkat kesehatan bank yang buruk maka memungkinkan masyarakat akan beralih ke bank-bank lain untuk menyimpan uangnya dan investor memilih bank lain untuk menanamkan modalnya. Jika hal ini terjadi, maka bank akan mengalami penurunan keuntungan, penurunan ini akan berdampak pada harga saham bank tersebut. Oleh karena itu, keberhasilan BPD dalam melaksanakan tugasnya sebagai lembaga keuangan daerah yang bermutu baik dapat dilihat atau ditinjau dari hasil penilaian tingkat kesehatan tersebut.

\section{Kajian Literatur}

Pada Undang Undang RI No. 10 Tahun 1998 mengenai Perbankan (pasal 1 ayat 2), menyebutkan bahwa bank adalah sebuah badan yang memberikan pelayanan bagi masyarakat yang ingin menyimpan dananya dalam bentuk simpanan, serta memberikan pelayanan menyalurkan dana dalam bentuk kredit. Hal ini dilakukan bertujuan untuk meningkatkan taraf hidup masyarakat. Berdasarkan fungsinya bank dibagi menjadi 2 yaitu yang pertama adalah bank umum, bank ini menjalankan kegiatan usahanya dengan prinsip syariah ataupun secara konvensional dengan memberikan jasa dalam lalu lintas pembayaranan. Jenis bank yang kedua adalah Bank Perkreditan Rakyat (BPR) bank ini menjalankan kegiatan usahanya dengan prinsip syariah ataupun secara konvensional dengan tidak memberikan jasa dalam lalu lintas pembayaranan.

BPD adalah bank yang berdiri sebagai mitra kerja pemerintah provinsi daerah yang bersangkutan. BPD menyediakan layanan dan produk seperti bank umum lainnya. Layanan menghimpun dana dan menyalurkan dana, kemudian berbagai macam produk 
kredit mulai dari segmen produktif dan segmen konsumtif. Dimana contoh dari segmen produktif seperti investasi dan modal usaha, dan contoh segmen konsumtif seperti kredit tanpa jaminan. Sedangkan untuk produk dananya berupa deposito, tabungan, dan giro. Berdasarkan Undang-Undang Republik Indonesia Nomor 13 tahun 1962 tentang ketentuan-ketentuan pokok bank pembangunan daerah didirikan untuk menyediakan pembiayaan untuk pelaksanaan usaha pembangunan daerah.

Darmawi (2011) mendefinisikan kesehatan bank merupakan kepentingan yang dimiliki oleh banyak pihak, mulai dari nasabah, manajemen, sampai yang terpenting adalah pemilik, dimana Bank Indonesia berperan sebagai pengawas seluruh bank yang ada di Indonesia. Menurutnya kesehatan bank ini sangat penting, karena cukup memberikan dampak pada perekonomian Indonesia. Penilaian tingkat kesehatan perbankan di Indonesia wajib untuk dilakukan seluruh bank di Indonesia. Penilaian ini dilakukan melalui pendekatan risiko (RiskBased Bank Rating/RBBR) yang cakupan penilaiannya meliputi faktor profil risiko, Good Corporate Governance (GCG), rentabilitas, dan faktor permodalan.

Pengertian dari harga saham adalah harga yang telah ditentukan oleh suatu perusahaan untuk diberikan kepada pihak yang ingin menjadi bagian dari pemilik perusahaan. Harga saham juga dapat diartikan sebagai harga yang terbentuk dari proses permintaan dan penawaran atas saham suatu perushaan di pasar efek. Jumlah lembar saham yang dimiliki oleh investor menunjukkan total nilai aset yang dimiliki. Harga saham yang semakin tinggi mencerminkan nilai yang dimiliki perusahaan. Harga saham juga bisa menunjukkan keadaan atau kondisi industri yang bersangkutan dan juga kondisi ekonomi negara. Menurut Sartono (2011:192) harga saham terbentuk dari mekanisme penawaran dan permintaan yang terjadi di pasar modal, jika harga suatu saham mengalami kelebihan permintaan maka yang terjadi adalah harga saham cenderung naik.

$H 1$ : Terdapat pengaruh signifikan secara simultan (bersama-sama) antara variabel tingkat kesehatan bank yaitu NPL, LDR, GCG, ROA, NIM, dan CAR terhadap harga saham BPD yang terdaftar di Bursa Efek Indonesia (BEI) tahun 2014-2018. 
H2 : Terdapat pengaruh signifikan secara parsial variabel NPL terhadap harga saham BPD yang terdaftar di Bursa Efek Indonesia (BEI) tahun 2014-2018.

H3 : Terdapat pengaruh signifikan secara parsial variabel LDR terhadap harga saham BPD yang terdaftar di Bursa Efek Indonesia (BEI) tahun 2014-2018.

H4 : Terdapat pengaruh signifikan secara parsial variabel GCG terhadap harga saham BPD yang terdaftar di Bursa Efek Indonesia (BEI) tahun 2014-2018.

H5 : Terdapat pengaruh signifikan secara parsial variabel ROA terhadap harga saham BPD yang terdaftar di Bursa Efek Indonesia (BEI) tahun 2014-2018.

H6 : Terdapat pengaruh signifikan secara parsial variabel NIM terhadap harga saham BPD yang terdaftar di Bursa Efek Indonesia (BEI) tahun 2014-2018.

H7 : Terdapat pengaruh signifikan secara parsial variabel CAR terhadap harga saham BPD yang terdaftar di Bursa Efek Indonesia (BEI) tahun 2014-2018.

Gambar 1. Bagan Hipotesis

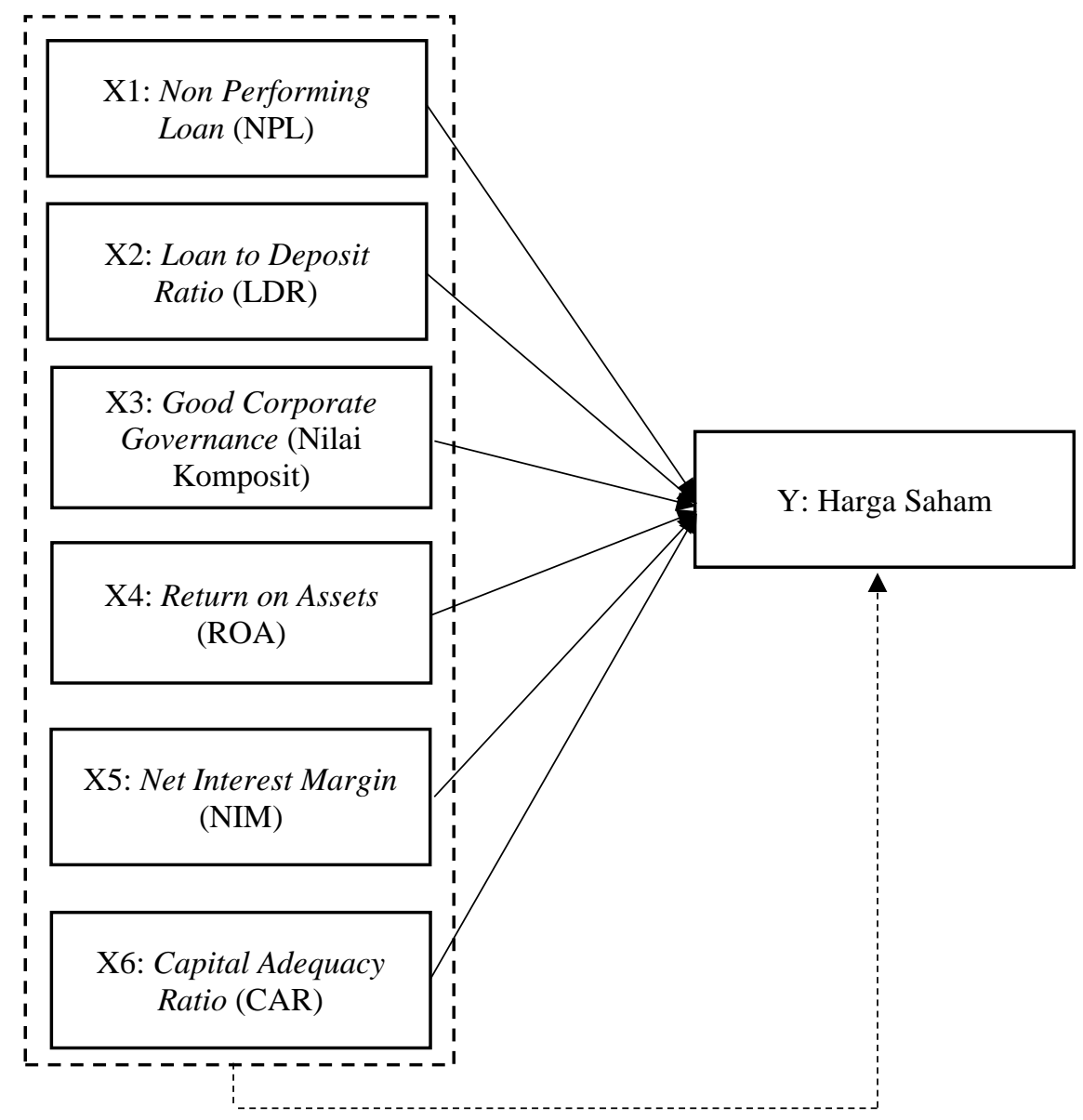


Keterangan:

1. Garis putus-putus: hubungan simultan

2. Garis bersambung: hubungan parsial

\section{Metode Penelitian}

Berdasarkan metodenya, penelitian merupakan penelitian kuantitatif. Sugiyono (2013:13) menjelaskan bahwa penelitian kuantitatif merupakan penelitian yang dilandaskan pada filsafat positivisme, dimana penelitian kuantitatif digunakan untuk penilitian pada populasi ataupun sampel tertentu. Berdasarkan tujuannya, penelitian ini bersifat kausal. Bertujuan untuk mencari hubungan dari beberapa variabel. Sugiyono (2012:59) mendefinisikan hubungan kausal sebagai hubungan yang terbentuk karena adanya sebab dan akibat. Berdasarkan keterlibatan peneliti terhadap data, penelitian ini bersifat tidak mengintervensi data maksudnya adalah data yang digunakan tidak dibentuk atau tidak disusun sendiri dari awal oleh peneliti yang bersangkutan. Berdasarkan dimensi waktu, penelitian ini menggunakan data yang termasuk dalam jenis data runtut waktu (time series).

Nazir (2005) mendefinisikan populasi sebagai sekelompok individu yang memiliki karakter dan kualitas yang telah ditetapkan oleh peneliti.. Populasi yang akan digunakan pada penelitian ini sebanyak 110 bank yang merupakan Bank Umum yang ada di Indonesia. Sugiyono (2008: 118) menerangkan bahwa sampel adalah suatu bagian dari populasi mulai dari jenis, karakteristik, bahkan kesuluruhan yang ada pada sebuah populasi. Teknik pengambilan sampel (sampling) pada penelitian ini menggunakan metode purposive sampling, dimana sampel akan diambil ketika memenuhi kriteria atau syarat yang telah ditentukan. Adapun beberapa kriteria dan syarat pemilihan sampel adalah sebagai berikut:

1. Bank Umum Konvensional yang termasuk dalam Bank Pembangunan Daerah di Indonesia.

2. Bank Pembangunan Daerah yang telah terdaftar di Bursa Efek Indonesia (BEI) sejak tahun 2014-2018.

3. Bank Pembangunan Daerah di Indonesia yang laporan tahunannya (annual report) tersedia selama tahun 2014-2018. 
4. Bank Pembangunan Daerah yang mencantumkan data peringkat Good Corporate Governance (GCG) selama

tahun 2014-2018.

Table 1. Daftar Sampel

\begin{tabular}{cl}
\hline No. & \multicolumn{1}{c}{ Nama Bank } \\
\hline $\mathbf{1}$ & BPD BANTEN TBK \\
\hline $\mathbf{2}$ & BPD JAWA BARAT DAN BANTEN TBK \\
\hline $\mathbf{3}$ & BPD JAWA TIMUR TBK \\
\hline
\end{tabular}

Data yang digunakan dalam penilitian ini adalah data kuantitatif dengan skala rasio serta bersumber dari data sekunder. Kasiram (2008) menjelaskan pengertian dari penelitian kuantitatif adalah sebuah metode penelitian yang analisisnya menggunakan data dalam bentuk angka serta menganalisis melalui penelitian terdahulu. Data yang digunakan berupa data sekunder yang mana datanya bukan diolah langsung oleh penulis melainkan data yang sudah dipublikasi dan sudah siap dipakai langsung. Data yang digunakan berasal dari laporan tahunan bank yang didapat melalui situs resmi BPD yang bersangkutan dan data harga saham berasal dari situs resmi Bursa Efek Indonesia (BEI).

Sugiyono (2004:169) mengatakan bahwa analisis deskriptif adalah statistik yang fungsinya untuk analisa sebuah data dengan cara membuat deskripsi atas data yang yang telah dikumpulkan, namun pendeskripsian data ini ditulis seperti adanya tanpa membuat kesimpulan yang generalisasi, maksudnya adalah kesimpulan dibuat secara umum.

Sebuah model regresi linear Ordinary Least Square (OLS) akan dinilai melalui analisis uji asumsi klasik apakah dalam model regresi linear OLS tersebut terdapat masalah asumsi klasik atau tidak. Mengingat data penelitian yang digunakan adalah sekunder, maka dari itu diperlukan adanya pengujian pada beberapa asumsi klasik diantaranya yaitu uji multikolinearitas, uji normalitas data, uji autokorelasi, dan uji heteroskedastisitas.

Teknik analisis yang digunakan pada penelitian ini yaitu teknik analisis regresi linear berganda yang bertujuan untuk mendapatkan gambaran secara menyeluruh mengenai 
besarnya pengaruh dari variabel independen yaitu variabel NPL, LDR, GCG, ROA, NIM, dan CAR terhadap variabel dependen yaitu harga saham.

Menurut Ghozali (2018) uji F adalah uji signifikan secara keseluruhan dari variabel bebas terhadap garis regresi yang diobservasi ataupun estmasi, apakah variabel terikat berhubungan linear terhadap variabel bebas. Kriteria penerimaan hipotesis menurut Riyano (2020) adalah sebagai berikut:

a. $H_{0}=0$ : tidak ada pengaruh signifikan secara simultan variabel independen terhadap variabel dependen

b. $H_{\mathrm{a}} \neq 0$ : tidak ada pengaruh signifikan secara simultan variabel independen terhadap variabel dependen

Pengambilan keputusan uji F menurut (Riyanto dan Hatmawan, 2020:141) adalah sebagai berikut:

a. Jika F hitung $<\mathrm{F}$ tabel atau sig $>0,05$, maka $H_{0}$ diterima

b. Jika $\mathrm{F}$ hitung $\geq \mathrm{F}$ tabel atau sig $\leq 0,05$, maka $H_{0}$ ditolak

Uji t digunakan untuk melihat apakah parameter regresi dianggap signifikan atau tidak. Uji parsial digunakan untuk melihat seberapa besar pengaruh variabel independen terhadap variabel dependen secara parsial (sendiri sendiri). Ketetapan kriteria (Riyanto dan Hatmawan, 2020:141) adalah sebagai berikut:

a. $H_{0}=0$ : tidak ada pengaruh yang signifikan variabel independen terhadap variabel dependen

b. $H_{\mathrm{a}} \neq 0$ : terdapat pengaruh yang signifikan variabel independen terhadap variabel dependen

Pengambilan keputusan uji parsial (Riyanto dan Hatmawan, 2020:141) adalah sebagai berikut:

a. $\quad H_{0}$ diterima jika nilai $t_{\text {hitung }}<t_{\text {tabel }}$ atau $-t_{\text {hitung }}>-t_{\text {tabel }}$ atau nilai sig $>0,05$

b. $\quad H_{0}$ ditolak jika nilai $t_{\text {hitung }} \geq t_{\text {tabel }}$ atau $-t_{\text {hitung }} \leq-t_{\text {tabel }}$ atau nilai sig $\leq 0,05$

Menurut Ghozali (2009) uji koefisien determinasi intinya adalah menghitung seberapa jauh kemampuan sebuah model dalam menerangkan variasi variabel dependen, rentang nilai dari koefisien determinasi adalah antara nol dan satu. Koefisien determinasi menjelaskan pengaruh yang diberikan variabel independen terhadap variabel dependen.

\section{Hasil Penelitian}

Standar kepastian dalam pengujian reliabilitas memanfaatkan teknologi Alpha Cronbach. Jika memiliki faktor reliabilitas atau alpha melebihi dari 0,6, dapat dipastikan. Cronbach's Alpha bernilai tidak lebih besar dari 0,6. pada tabel sebagai berikut: 
Tabel 1. Hasil Uji Reliabilitas

\begin{tabular}{|c|c|c|c|}
\hline & Cronbach's Alpha & & \\
\hline Variabel & & Kriteria & Keterangan \\
\hline $\begin{array}{l}\text { Pemberian Insentif } \\
\text { (X1) }\end{array}$ & 0,887 & 0,6 & Reliabel \\
\hline Tanggung Jawab (X2) & 0,879 & 0,6 & Reliabel \\
\hline Kinerja Karyawan (Y) & 0,879 & 0,6 & Reliabel \\
\hline
\end{tabular}

Sumber : Data Penelitian (2020).

Memanfaatkan studi ini, para peneliti melakukan analisis grafik dengan menggunakan plot histogram dan Normal P- P Plot of Regression Standardized Residual dan tes ndonesia melalui uji Kolmogrov Smirnov (KS), pada Gambar sebagai berikut :

Gambar 2. Uji Normalitas Kurva Histogram

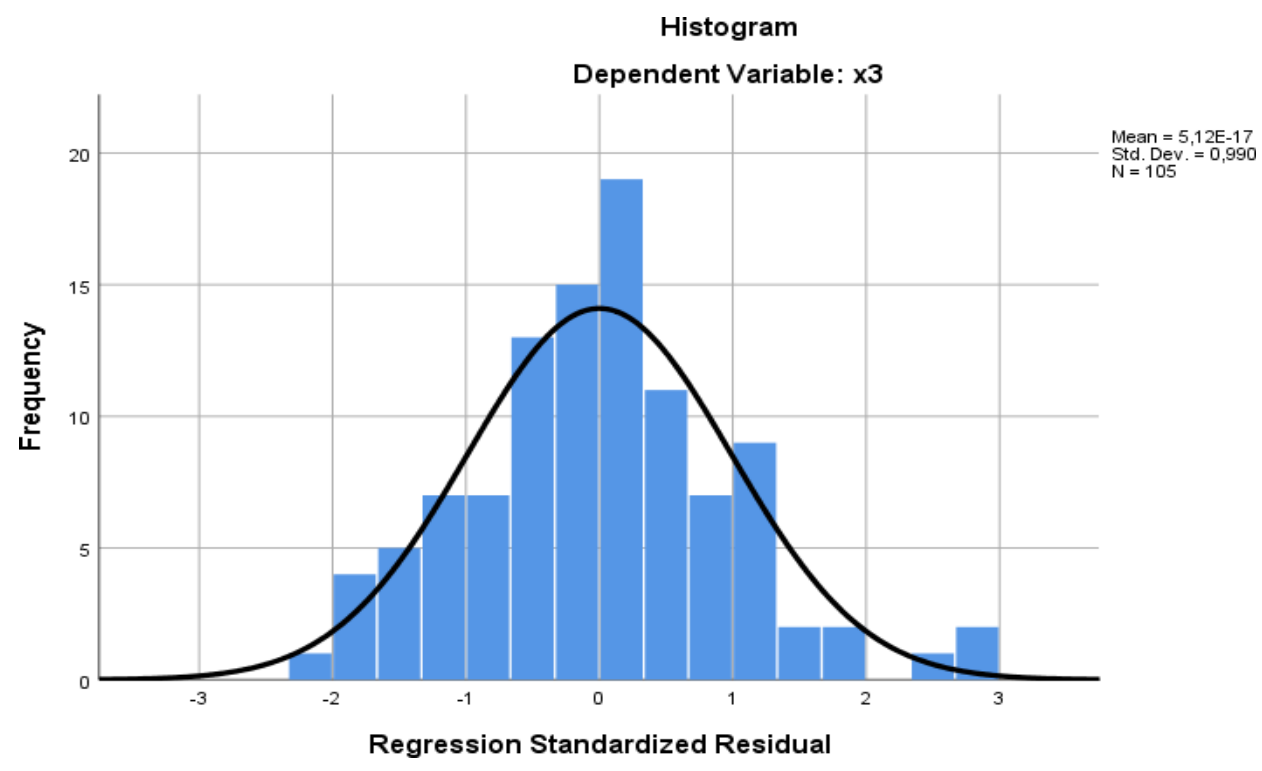

Sumber : Data Penelitian (2020)

Tabel 2. Hasil Uji Koefisien Determinasi

\begin{tabular}{lccccccc}
\hline Model & \multirow{2}{*}{$\mathrm{R}$} & $\mathrm{R}$ & $\begin{array}{c}\text { Adjust } \\
\text { Squre }\end{array}$ & $\mathrm{R}$ & $\begin{array}{c}\text { Std. } \\
\text { Estimate }\end{array}$ & ofror the \\
\hline 1 &, $632^{\mathrm{a}}$ & & Square & 399 &, 387 & 2,681 & \\
\hline
\end{tabular}

Sumber : Data Penelitian (2020)

Dapat diperhatikan dari tabel di atas bahwa nilai (R2) dari hasil uji koefisien determinasi adalah 0,399. Ini berarti bahwa dalam model regresi ini, persentase variabel pemberian insentif dan 
tanggung jawab adalah 39,9\%, selain itu perolehan hasil variabel lain (hingga 60,1\%) terpengaruhi oleh faktor-faktor lain yang mempengaruhi kinerja karyawan PT Yongda Plastics ndonesia di Batam.

Tabel 3. Hasil Uji F

\begin{tabular}{lllllll}
\hline Model & & $\begin{array}{l}\text { Sum of } \\
\text { Square }\end{array}$ & df & $\begin{array}{c}\text { Mean } \\
\text { Square }\end{array}$ & F & Sig. \\
\hline \multirow{2}{*}{1} & Regression & 486,595 & 2 & 243,480 & 33,881 &, $000 \mathrm{~b}$ \\
& & & & & \\
& Residual & 733,003 & 102 & 7,186 & & \\
\hline
\end{tabular}

Sumber : Data Penelitian (2020)

Menurut Tabel di atas, variabel "pemberian insentif" dan "tanggung jawab" secara simultan mempunyai pengaruh positif dan signifikan terhadap kinerja karyawan. Nilai $\mathrm{F}$ yang dihitung positif pada 33,881, dan nilai signifikan 0,000 tidak lebih besar dari angka $\alpha 0,05$. Sehingga bisa dipastikan diterimanya hipotesis ketiga.

\section{Pembahasan}

Untuk mengetahui pengaruh masing-masing variabel independen terhadap variabel dependen, hasil yang diperoleh pada Tabel 3 menunjukkan bahwa variabel yang diberikan insentif memiliki pengaruh positif sebesar 3.137, dan signifikansi 0,003 tidak melebihi nilai $\alpha 0,05$. Oleh karena itu dapat dipastikan hipotesis pertama dari penelitian ini menunjukkan bahwa variabel insentif berpengaruh signifikan terhadap kinerja karyawan PT Yongda Plastics Indonesia. Koefisien regresi pemberian insentif variabel positif berarti bahwa meningginya angka pemberian insentif, meninggi juga angka kinerja karyawan. Pemberian insentif dapat meningkatkan kinerja karyawan PT Yongda Plastics Indonesia.

Berdasarkan hasil yang digunakan untuk mengetahui pengaruh masing-masing variabel bebas terhadap variabel terikat, hasil uji-t pada Tabel 3 menunjukkan bahwa pengaruh positif variabel yang bertanggung jawab sebesar 2,513 dan signifikansi 0,018 lebih kecil dari $\alpha 0,05$. Sehingga bisa dikatakan diterimanya hipotesis kedua, yang menunjukkan bahwa variabel tanggung jawab PT Yongda Plastics Indonesia di Batam mempunyai pengaruh yang signifikan terhadap kinerja karyawan. Variabel koefisien tanggung jawab memiliki nilai positif, yang mempunyai arti bahwa meningginya angka tanggung jawab, semakin tinggi pula angka kinerja karyawan. Dampak Tanggung Jawab menyatakan hasil 
yang positif dan signifikan dalam kinerja karyawan terhadap Kinerja Karyawan PT Yongda Plastics Indonesia. Hasil penelitian yang selalu menguji pengaruh partisipasi anggaran terhadap kinerja manajerial juga mendukung hal tersebut (Ermawati, 2017; Jatmiko, 2017; Giusti et al., 2018; Pratiwi, 2019; Andison \& Augistine, 2017; Marlina, 2019). Dari penelitian ini diketahui bahwa partisipasi dalam penyusunan anggaran memiliki pengaruh yang signifikan terhadap kinerja manajemen. Oleh karena itu dapat dikatakan bahwa penelitian ini mendukung hasil penelitian yang dilakukan oleh peneliti sebelumnya.

Tanggung Jawab yang dimaksud adalah kegiatan perusahaan yang diserahkan kepada karyawan baik secara langsung dan tidak langsung besarnya tanggung jawab yang dikerahkan kepada karyawan maka bisa menaikkan Kinerja Karyawan PT Yongda Plastics Indonesia.

Menurut hasil uji-F yang diteliti demi menentukan efek simultan variabel pemberian insentif dan tanggung jawab terhadap kinerja karyawan, hasil uji-F yang diperoleh dalam menunjukkan bahwa variabel pemberian insentif dan tanggung jawab secara simultan memiliki dampak positif senilai 33.881, dan secara signifikan 0,00 tidak lebih besar dari angka $\alpha 0,05$. Temuan penelitian ini berasal dari penelitian sebelumnya (Lamato, 2017; Adhiputra, 2019; Laiya \& Pondaag, 2018; Komara, 2017). Maka bisa dikatakan bahwa hipotesis ketiga penelitian ini menyatakan bahwa variabel pemberian insentif dan tanggung jawab mempunyai pengaruh signifikan terhadap kinerja karyawan PT Yongda Plastics Indonesia.

\section{Kesimpulan}

Variabel tingkat kesehatan bank yang terdiri dari faktor profil risiko (risk profile) yang diukur menggunakan rasio NPL dan LDR, faktor tata keolola perusahaan yang diukur dengan nilai komposit GCG secara keseluruhan, faktor rentabilitas yang diukur dengan menggunakan rasio ROA dan NIM, dan faktor permodalan yang diukur dengan menggunakan rasio CAR secara bersama-sama (simultan) berpengaruh secara signifikan terhadap harga saham BPD yang terdaftar di BEI tahun 2014-2018. Faktor profil risiko yang diukur menggunakan rasio NPL secara parsial berpengaruh signifikan terhadap 
harga saham BPD yang terdaftar di BEI tahun 2014-2018. Faktor profil risiko yang diukur menggunakan rasio LDR secara parsial tidak berpengaruh signifikan terhadap harga saham BPD yang terdaftar di BEI tahun 2014-2018. Faktor tata keolola perusahaan (good corporate governance) yang diukur dengan nilai komposit secara keseluruhan secara parsial tidak berpengaruh signifikan terhadap harga saham BPD yang terdaftar di BEI tahun 2014-2018. Faktor rentabilitas yang diukur dengan menggunakan rasio ROA secara parsial tidak berpengaruh signifikan terhadap harga saham BPD yang terdaftar di BEI tahun 2014- 2018. Faktor rentabilitas yang diukur dengan menggunakan rasio NIM secara parsial tidak berpengaruh signifikan terhadap harga saham BPD yang terdaftar BEI tahun 2014-2018. Faktor permodalan yang diukur dengan menggunakan rasio CAR secara parsial tidak berpengaruh signifikan terhadap harga saham BPD yang terdaftar di BEI tahun 2014-2018.

\section{Referensi :}

Adhiputra, M. W. (2019). Analisis Penerapan Tqm Terhadap Kinerja Manajerial Pada Rumah Sakit Umum Di Denpasar. JIA (Jurnal Ilmiah Akuntansi), 3(1). http://dx.doi.org/10.23887/ jia.v3i1. z16628

Ahmad, H., Mappatompo, A., \& Muslim, M. (2018). Capital Ownership Structure And Decision On Fi-financial Market Reaction And Corporate Value. International Journal of Innovative Science and Re-search Technology, 3(9), 395-406. https://doi.org/10.1016/i.jinteco.2013.10.007

Andison, A., \& Augustine, Y. (2017). Partisipasi Anggaran, Kepuasan Kerja, dan Kinerja Manajerial: Studi Pada Bisnis Keluarga Pempek di Kota Palembang. Esensi: Jurnal Bisnis dan Manajemen, 7(1), 73-82

Basalamah, J., Pramukti, A., \& Basalamah, A. (2019). Kemampuan, Komitmen Dan Sarana Prasarana Terhadap Kinerja Pegawai Rumah Sakit. CESJ: Center of Economic Students Journal, 2(2), 153-164.

Effendy, A. A., \& Fadhilah, A. (2019). Pengaruh Insentif Dan Motivasi Terhadap Kinerja Karyawan Pada Pt. Calibramed Jakarta Selatan. Jimf (Jurnal Ilmiah Manajemen Forkamma), 1(3), 85-96. https://doi.org/10.32493/frkm.v1i3.2551

Ermawati, N. (2017). Pengaruh Partisipasi Anggaran terhadap Kinerja Manajerial dengan Motivasi Kerja sebagai Variabel Pemoderasi (Studi Kasus SKPD Kabupaten Pati). JurnalAkuntansi Indonesia, 6(2), 141-156 
Giusti, G., Kustono, A. S., \& Effendi, R. (2018). Pengaruh Partisipasi Anggaran Terhadap Kinerja Manajerial dengan Komitmen Organisasi dan Motivasi Sebagai Variabel Intervening. e-Journal Ekonomi Bisnis dan Akuntansi, 5(2), 121-128.

Irawati, R., \& Carollina, D. A. (2017). Analisis Pengaruh Beban Kerja Terhadap Kinerja Karyawan Operator Pada Pt Giken Precision Indonesia. Inovbiz: Jurnal Inovasi Bisnis, 5(1), 51. https://doi.org/10.35314/inovbiz.v5i1.171

Khan, A. A., Abbas, N., \& Zaki, K. A. (2017). Effect of incentives based two factor theory on employee performance in telecom sector of Pakistan. The Nucleus, 54(3), 173-180.

Lamato, B. R., Jan, A. B. H., \& Karuntu, M. M. (2017). Analisis Total Quality Management (TQM) Terhadap Kinerja Manajerial Pada PT. Asegar Murni Jaya Desa Tumaluntung KAB. Minahasa Utara. Jurnal EMBA: Jurnal Riset Ekonomi, Manajemen, Bisnis dan Akuntansi, 5(2).

Laiya, R. A. R., Jan, A. B. H., \& Pondaag, J. J. (2018). Pengaruh Total Quality Management (Tqm) Terhadap Kinerja Manajerial Pada Pt. Bank Mandiri (Persero) Tbk Area Manado. Jurnal EMBA: Jurnal Riset Ekonomi, Manajemen, Bisnis dan Akuntansi, 6(4). https:// doi.org/10.35794/emba.v6i4.21047

Marlina, E., \& Zega, B. L. (2019). AnalisisDeterminasi Kinerja Manajerial: Studi Empiris Pada Rumah Sakit Umum Daerah Propinsi Riau. Muhammadiyah Riau Accounting and Business Journal, 1(1), 1-9

Nasir, M. (2020). Etika dan Komunikasi dalam Bisnis: Tinjauan Al-Qur'an, Filsafat dan Teoritis. CV. Social Politic Genius (SIGn).

Nisa, F., Suharman, H., \& Hasyir, D. A. (2020). Ketidakpastian Permintaan Pelanggan Sebagai Pemicu Manajemen Persediaan Dengan Pendekatan Analisis FSN. Syntax Literate; Jurnal Ilmiah Indonesia, 5(4), 56-63. http://dx.doi.org/10.36418/syntaxliterate.v5i4.1067

Pratiwi, W., \& Kartika, A. A. (2019). Pengaruh Akuntansi Pertanggungjawaban, Komitmen Organisasi, Dan Partisipasi Anggaran Terhadap Kinerja Manajerial. Wahana: Jurnal Ekonomi, Manajemen dan Akuntansi, 22(1), 50-60

Riyanto, S., \& Hatmawan, A. A. (2020). Metode Riset Penelitian Kuantitatif Penelitian Di Bidang Manajemen, Teknik, Pendidikan Dan Eksperimen. Deepublish.

Rifa, M. N., Sukidjo, S., \& Efendi, R. (2019). The Performance of Employees Influenced by Leadership Styles and Compensation. International Journal of Multicultural and 
Multireligious Understanding, 6(6), 581-587. http://dx.doi.org/10.18415/ijmmu. $\underline{\text { v6i6.1243 }}$

Sugiyono, S. (2010). Metode penelitian kuantitatif dan kualitatif dan R\&D.

Wiryana, L., \& Augustine, Y. (2014). Pengaruh Karakteristik Informasi Sistem Akuntansi Manajemen terhadap Kinerja Manajerial dengan Variabel Moderasi Strategi Bisnis, Perceived Environmental Uncertainty (Peu), Ketidakpastian Tugas dan Desentralisasi. Jurnal Magister Akuntansi Trisakti, 1(2), 155-180 